\title{
Land Suitability Evaluation Of New Settlement For Citizen Affected By The Construction Of Cisokan Reservoir In West Bandung
}

\author{
Luthpi Padhlulloh' ${ }^{1}$, arikesit $^{2}$, and Firman Hadi, ${ }^{3}$ \\ ${ }^{1}$ Environment Science Program, Postgraduate School, Universitas Padjadjaran, Indonesia. \\ ${ }^{2}$ Center for Environment \& Sustainability Science, Padjadjaran University, Indonesia. \\ ${ }^{3}$ Lecture at Geodesy Engineering Department, Faculty of Engineering, Universitas Diponegoro, Indonesia.
}

\begin{abstract}
The construction of the Cisokan Reservoir caused residents who previously lived and carried out activities around the land that would be inundated to have to move to another place. Based on the Land Acquisition and Relocation report, 10 locations were selected and already occupied by residents affected by the construction of the Cisokan Reservoir to be used as new residential land. An increase in the population of a space in a certain period of time is accompanied by an increase in the need for land, especially for housing needs. In an agrarian society, land is also needed for a production function. Land use for settlements must be regulated by taking into account ecological aspects so as not to cause problems and disasters in the future. With the Geographical Information System approach with the spatial scoring technique, the final results obtained at the research location were 3 land suitability classes, namely S1, S2, and S3 classes. The land suitability class $\mathrm{N}$ was not found in the study area. Meanwhile, for the resettlement locations of residents affected by the construction of the Cisokan reservoir from the 10 locations, all locations are in areas with land suitability class S2.
\end{abstract}

\section{Introduction}

Planning for the development of the Cisokan Reservoir, which is located in two districts in West Java Province, namely Cianjur Regency and West Bandung Regency, aims to produce electrical energy by utilizing water resources. Electrical energy is needed to support people's lives and activities, together with an increase in population and an increase in development in various sectors, especially in the agricultural sector. With the increasing need for electrical energy, especially in the Java-Bali region, the government through PT PLN (National Electricity Company) is planning to build 1,040 MW PLTA Upper Cisokan Pumped Storage (UCPS) in the Cisokan River Basin, West Java Province. The Upper Cisokan hydropower plant will have two reservoirs (upper reservoir and lower reservoir), each with an active volume of $10,000,000 \mathrm{~m}^{3}$, a total volume of an upper reservoir of $14,000,000 \mathrm{~m}^{3}$ and a total volume of a lower reservoir of $63,000,000 \mathrm{~m}^{3}$ [7]. The use of reservoirs is considered effective especially in some areas in In Indonesia, the intensity of rainfall is quite high, so that the construction of reservoirs is considered effective and environmentally friendly, especially in an effort to produce electrical energy $[6,9]$.

However, the reservoir construction process itself has had various negative impacts. It has long been known that reservoir development leads to population displacement, loss of biodiversity, ecosystem functions and services, changes in land use, changes in land cover and loss of livelihoods for villagers who depend on the agricultural sector $[2,3]$. In the construction process of the Cisokan Reservoir itself, the land affected by the development project covers an area of 360,819 hectares, mostly agricultural land consisting of rice fields (189.74 hectares), yards (120.33 hectares), and a total of 1,035 building units affected with an area of around 50.749, 4 $\mathrm{m}^{2}[8]$.

The process of reservoir development causes changes in land use and changes in the physical environment. In addition, the need for population growth, apart from land reservoir development, is also needed for the process of moving people affected by land acquisition through development. Under these conditions the pressure on land residents increases. In an agrarian society the need for land is increasing because in addition to housing (houses), land is also needed for the production process. So that the community must divide the existing land according to their needs. Thus, in an ecological system, the physical environment is closely related to social conditions and both of them influence each other [5].

In several experiences of reservoir development in West Java, according to $[1,4,10]$ stated that residents affected by the construction of the reservoir, prefer to relocate themselves or independently, even though the process is regulated in groups. No exception in the process of building the cisokan reservoir. Based on the Land Acquisition And Resettlement Action Plan [7], most residents prefer to relocate independently by 
moving to the location of the land they have prepared, compared to relocating to a place that has been facilitated by the government. The process of relocating residents itself began at the end of 2014 to 2020, with 101 heads of families affected, previously residing in 9 sub-villages which are included in 3 villages namely Bojong Salam Village, Cicadas Village, and Sukaresmi Village . In carrying out relocation independently, there are 10 choices of locations chosen by residents to carry out relocation independently, namely:

1. Kampung Pasir Jegud/Tapos, Sukaresmi Village. Rongga Sub-District, Bandung Barat.

2. Kampung Cidongke, Bojong Village. Rongga Sub-District, Bandung Barat District.

3. Kampung Munjul, Bojong Village. Rongga Sub-District, Bandung Barat District.

4. Kampung Santik, Bojong Village. Rongga Sub-District, Bandung Barat District.

5. Kampung Cihaneut, Cinengah Village. Rongga Sub-District, Bandung Barat District.

6. Kampung Cangkuang, Bojongsalam Village. Rongga Sub-District, Bandung Barat District.

7. Kampung Jolok, Cicadas Village. Rongga SubDistrict, Bandung Barat District.

8. Kampung Gunung Batu, Cicadas Village. Rongga Sub-District, Bandung Barat District.

9. Kampung Pasir Laja, Sukaresmi Village. Rongga Sub-District, Bandung Barat District.

10. Kampung Babakan Bandung, Sukaresmi Village. Rongga Sub-District, Bandung Barat District.

Based on the Land Acquisition And Resettlement Action Plan report [7], in determining the location of resettlement. The residents chose the location for various reasons. However, the main reason for the majority of residents stated that, the land provided by the government was far away from their resources or cultivated land. Meanwhile, the land that was selected independently had access that was easier to reach or not too far away from the land resources they cultivated. Thus, choosing the location of relocation for residents can be said to pay more attention to the economic side or the production process in their livelihoods compared to the ecological side of the resettlement location. However, agrarian communities who work as farmers have different preferences in determining which areas are used as settlements [11].

On the other hand, with physical conditions that are not too much attention while there is an increase in the number of people in a space at a certain time, of course, it will increase the chances of a decrease in environmental quality [9]. Meanwhile, the concept for the construction of the Upper Cisokan Pumped Storage Hydropower (UCPSH) uses a green energy approach. The green energy concept is characterized in that each component of its development has international standard guidelines to pay attention to environmental and social conditions.

However, until the time this research was conducted, no information or scientific study was available regarding the physical conditions for the relocation area. Thus, assessing the suitability of land for resettlement areas, it seems that the construction of the Cisokan Dam is important. This research was conducted using a Geographical Information System (GIS) approach. The GIS approach was chosen because of its ability to provide information about the spatial diversity on the earth's surface quickly, broadly, precisely, and easily.

The results of this study are expected to be a source of information about the suitability of land for new settlements and become a source of fundamental data in the development process, especially the construction of reservoirs so as not to cause problems and disasters in the future in accordance with Indonesian government policy, namely Law Number 1 of 2011 concerning Housing. Settlement Areas, which are intended to maintain the function of housing and settlement areas in a good and sustainable manner for the benefit of improving the quality of life the community. In addition, it is also a basis for improving environmental management and a strategic environmental study for sustainable development, especially in planning for habitable settlements.

\section{Material And Methods}

The research method used is the quantitative method approach with the Geographic Information System (GIS) approach analysis tool, while the spatial analysis technique used is the scoring and overlay method approach. In this study, the research area was carried out based on the village administrative approach of the 10 new settlement locations. Of the 10 locations are administratively entered into 5 villages, namely Sukaresmi Village, Cinengah Village, Bojong Village, Bojong Salam Village, and Cicadas Village which are part of the Rongga sub-district area of West Bandung Regency, for more details regarding the scope of the research area and location The new settlement is shown in Fig. 1.

In this study, the data sources are basic physical data relating to the suitability of land for residential areas according to the PERMEN PU No. 41/PRT/M/2007, in the technical explanation in the PERMEN, the characteristics of land suitability for residential areas must pay attention to the following conditions: 1). Flat to undulating topography (slope of land $0-25 \%$ ); 2 ). There is a sufficient amount of water, both ground water and water treated by the organizer. For PDAM water, the water supply is between 60 liters/person/day - 100 liters/person/ day; 3). Not in disaster-prone areas (landslides, floods, erosion, abrasion); 4). Good to moderate drainage; 5). Not in the river/beach/reservoir/lake/spring/ irrigation channel/railroad border areas and safe flight areas; 6). Not in a protected area; 7). Not located in an agricultural cultivation/buffer zone; 8). Avoid technical irrigation fields.

Provisions relating to physical conditions in the $\mathrm{PU}$ Regulation No. 41 / PRT / M / 2007 are used as variables and indicators in this study. In conducting the research process, the data used are indicators in determining the suitability of land for residential areas. The data used include slope, land cover, soil type, level of erosion and 
disaster-prone areas (flood-prone areas, landslide-prone areas and earthquake-prone areas). In this study, the primary data source is landscape spatial data from Google's high-resoulsi images, satellite images are obtained from the Google Earth Pro application with processing using the Arcmap 10.30 application. Image data is used to analyze land cover in 2013 or before the relocation of residents affected by the construction of the Cisokan Reservoir. Meanwhile, secondary data is DEM data from related institutions which will then be processed according to the indicators in this study. All data is displayed in the form of a map, previously carried out by the process of standardizing the map scale of each map source used, while the map scale changes to a scale of 1: 80,000 adjusted to the area of the study area.

Furthermore, from each of these indicators a scoring process is carried out. The total score of each indicator in the new residential area is then classified into four types of land suitability level for settlements where the highest total score describes the level of the most unsuitable residential land suitability, while the lowest total score represents the most suitable settlement land suitability level. The determination of the interval for each type of land suitability level uses the Sturgess calculation formula as follows:

$$
\begin{aligned}
& \text { Score Range }=\frac{\mathrm{Xmax}-\mathrm{Xmin}}{\mathrm{M}} \\
& \text { Information: } \\
& \mathrm{X} \max =\text { Highest score } \\
& \mathrm{Xmin} \quad=\text { Lowest score }
\end{aligned}
$$

$\mathrm{M}=$ Class total

Based on the calculation results obtained a minimum value of 70 and a maximum value of 370 while for the total class 4. By using the Sturgess calculation formula, the final result of the interval value for the land suitability class is 75 . The following is the interval value for each land suitability class as presented in Table 1.

Tabel 1. Scoring and land suitability class for residential areas

\begin{tabular}{ccl}
\hline $\begin{array}{c}\text { Suitability } \\
\text { Classes } \\
\text { (Score) }\end{array}$ & Code & \multicolumn{1}{c}{ Description } \\
$\begin{array}{c}\text { S1 } \\
(\mathbf{7 0 - 1 4 5 )}\end{array}$ & Highly Suitable & $\begin{array}{l}\text { Land has no significant boundaries or only a } \\
\text { few. }\end{array}$ \\
$\begin{array}{c}\text { S2 } \\
(\mathbf{1 4 6 - 2 2 1})\end{array}$ & Moderate Suitable & $\begin{array}{l}\text { Land has limitations for sustainable } \\
\text { application. }\end{array}$ \\
\hline $\mathbf{S 3}$ & Marginally Suitable & $\begin{array}{l}\text { The land has limitations in the severe } \\
\text { aggregate for sustainable use. }\end{array}$ \\
\hline $\mathbf{2 2 1 - 2 9 7 )}$ & Currently Not & $\begin{array}{l}\text { Land has limitations that may be overcome in } \\
\text { time but cannot be repaired with existing } \\
\text { knowledge and require large costs. }\end{array}$ \\
\hline
\end{tabular}

\section{Result And Discussion}

In the results and analysis based on the map of the research area (Fig. 2), the research location itself has an area of $8.849,957409 \mathrm{Ha}$, with the division of the area of Sukaresmi Village 2442,687955 Ha, Cicadas Village 2271,194165 Ha, Bojong Salam Village 1913,353362 $\mathrm{Ha}$, Bojong Village 1045,956 Ha, and Cinengah Village 1176,765926 , for the calculation of the area in percentage is shown in (Fig. 1). In order to facilitate the understanding process, in the discussion process the scoring process is carried out on each physical indicator, the land suitability class and the score displayed are the classes that exist in the research area, which is characterized by having an area in the research area. The results of the discussion of each physical indicator of land suitability for residential areas are as follows:

\subsection{Slope}

Based on the analysis result of the slope map (Figure 3) in the study area there are five classes of slopes. The study area is dominated by a Steep slope class $(25-45 \%)$ with an area of $3425.420664 \mathrm{Ha}$. Then

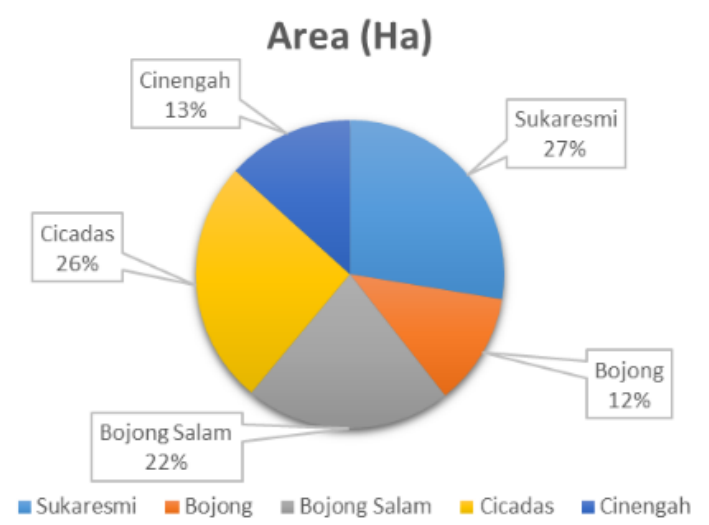

Fig.1. Research area in percentage

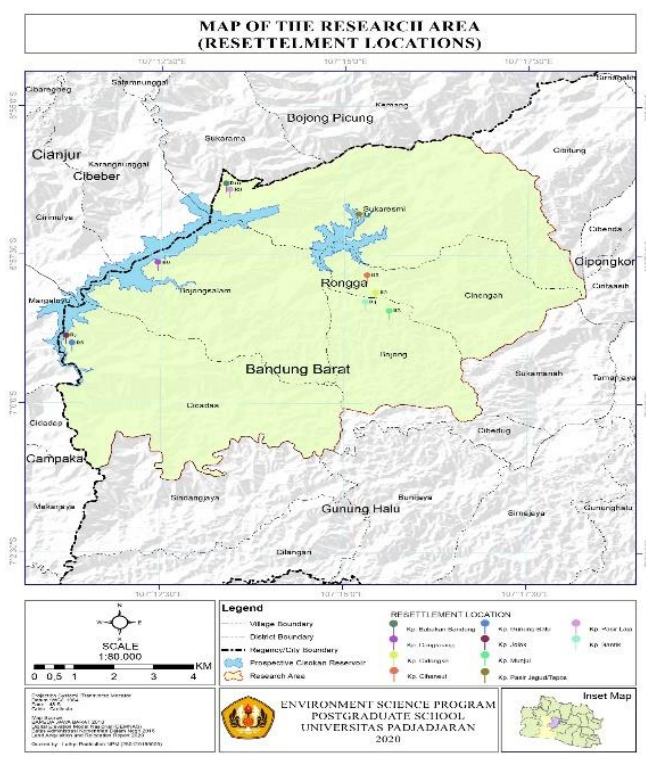

Fig.2. Map Of The Reasearch Location

followed by a Slightly Steep slope class (15-25\%) with an area of 2,003,244241 Ha. Furthermore, the slope class that dominates the study area with the third largest area is the Very Steep slope class (> 45\%) with an area of $1,972,90896 \mathrm{Ha}$ and in the fourth position is the Sloping class (8-15\%) with an area of $989,700789 \mathrm{Ha}$ and Flat slope class $(0-8 \%)$ with an area of 453.935821 
Ha. While the scores in each class are presented in Table 2.

Tabel 2. The scoring results for each class of slope

\begin{tabular}{ccc}
\hline Class of Slope & Area (Ha) & Score \\
\hline Flat $(0-8 \%)$ & 453,935821 & 20 \\
\hline $\begin{array}{c}\text { Sloping } \\
(8-15 \%)\end{array}$ & 989,700789 & 40 \\
\hline $\begin{array}{c}\text { Slightly Steep } \\
(15-25 \%)\end{array}$ & $2.003,244241$ & 60 \\
\hline $\begin{array}{c}\text { Steep } \\
(25-45 \%)\end{array}$ & $3.425,420664$ & 80 \\
\hline Very Steep $(>45 \%)$ & $1.972,90896$ & 100 \\
\hline
\end{tabular}

Meanwhile, for the resettlement area for residents affected by the construction of the Cisokan reservoir, of the 10 resettlement areas, 8 out of 10 are in the Slightly Steep area, 1 location is in Slopping and 1 is on Flat slopes. For more details, you can get in Table 3.

Table 3. The scoring results for each slope class at each resettlement location

\begin{tabular}{ccc}
\hline Resettlement Location & Kelas Lereng & Skor \\
\hline Kp.Pasir Jegud/Tapos & Slightly Steep & 60 \\
\hline Kp. Cidongke & Slightly Steep & 60 \\
\hline Kp. Munjul & Sloping & 40 \\
\hline Kp. Santik & Slightly Steep & 60 \\
\hline Kp. Cihaneut & Slightly Steep & 60 \\
\hline Kp. Cangkuang & Slightly Steep & 60 \\
\hline Kp. Jolok & Slightly Steep & 60 \\
\hline Kp. Gunung Batu & Slightly Steep & 60 \\
\hline Kp. Pasir Laja & Slightly Steep & 60 \\
\hline Kp. Babakan Bandung & Flat & 20 \\
\hline
\end{tabular}

\subsection{Land Cover}

The land cover map in the study area was obtained through the on-screen digitization method approach from high volume google earth images recorded on August 28, 2013, or a year before the relocation process was carried out by residents affected by the construction of the Cisokan reservoir. In 2013, there were 6 classes of land cover in the study area, namely Mixed Plantation, Rice Fields, Rice Fields, Open Land, Settlement Areas and Waters. While the research area is dominated by Mixed Gardens with an area of 6,527.1011129732 Ha. In giving a score on the land cover indicator, according to the land cover class contained in the study area, the following are the results of the scoring and area of each land cover class in the study area.

Table 4. The scoring results for each class of Land Cover

\begin{tabular}{lll}
\hline Class & Area (Ha) & Score \\
\hline Residental Area & 350,8853668 & 10 \\
\hline Empty Land & 210,4518291 & 20 \\
\hline Rice Field & $1.722,641284$ & 40 \\
\hline Field & 10,18883489 & 60 \\
\hline Mixed Plantation & $6.527,1011129732$ & 80 \\
\hline Water Body & 28,6889738390724 & 100 \\
\hline
\end{tabular}

Based on the results of observations and analysis of land cover maps in 2013 (Figure 4), for the resettlement locations of residents affected by the development of the Cisokan Reservoir, most or 7 locations were in locations that were previously residential areas, while the 2 locations were divided into
2 land cover classes , 1 location in an area that was previously a Mixed Plantation area and 1 location in an area previously occupied by Sawah. The scoring results obtained are as follows:

Table 5. The scoring results for each land cover class at each resettlement location.

\begin{tabular}{clc}
\hline Resettlement Location & $\begin{array}{c}\text { Class of Land } \\
\text { Cover }\end{array}$ & Skor \\
\hline Kp.Pasir Jegud/Tapos & Residental Area & 10 \\
\hline Kp. Cidongke & Residental Area & 10 \\
\hline Kp. Munjul & Residental Area & 10 \\
\hline Kp. Santik & Residental Area & 10 \\
\hline Kp. Cihaneut & Residental Area & 10 \\
\hline Kp. Cangkuang & Residental Area & 10 \\
\hline Kp. Jolok & Residental Area & 10 \\
\hline Kp. Gunung Batu & Residental Area & 10 \\
\hline Kp. Pasir Laja & Rice Field & 40 \\
\hline Kp. Babakan Bandung & Mixed Planatation & 80 \\
\hline
\end{tabular}

\subsection{Type Of Soil}

Based on the map of soil types 9 (Fig. 5), in the study area there are 2 types of soil and are dominated by Latosol soil with an area of $4470.454932 \mathrm{Ha}$. In addition, the research area also has Podsol soil types with an area of 4379.564325 hectares. Based on the criteria guidelines from PERMEN PU No.41/PRT/M/2007, explained that Soil types of Latosol is a quite sensitive to erosion with Moderate categories, while Podsol soil types are soil types that are sensitive to erosion with a Very High category. The scoring in the land suitability assessment for the residential area is as follows:

Table 6. The scoring results for each type of soil.

\begin{tabular}{ccc}
\hline Type Of Soil & Area (Ha) & Score \\
\hline Latosol & 4470,454932 & 30 \\
\hline Podsol & $4.379,564325$ & 60 \\
\hline
\end{tabular}

Meanwhile, based on map observations of 10 resettlement locations, 6 are in Latosol soil type, while 4 are in Podzol soil type. Meanwhile, the scoring results for each location are more clearly shown in the Table 7.

Table 7. The scoring results for each type of land at each resettlement location.

\begin{tabular}{ccc}
\hline Resettlement Location & $\begin{array}{c}\text { Type } \\
\text { Of Soil }\end{array}$ & Score \\
\hline Kp.Pasir Jegud/Tapos & Latosol & 30 \\
\hline Kp. Cidongke & Podsol & 60 \\
\hline Kp. Munjul & Podsol & 60 \\
\hline Kp. Santik & Podsol & 60 \\
\hline Kp. Cihaneut & Podsol & 60 \\
\hline Kp. Cangkuang & Latosol & 30 \\
\hline Kp. Jolok & Latosol & 30 \\
\hline Kp. Gunung Batu & Latosol & 30 \\
\hline Kp. Pasir Laja & Latosol & 30 \\
\hline Kp. Babakan Bandung & Latosol & 30 \\
\hline
\end{tabular}

\subsection{Rainfall}

Based on the results of the analysis of the 2010 West Java Province BAPEDA rainfall map, the research area has a daily rainfall of 2,500-3000 $\mathrm{mm} /$ day. In the Technical Guidance on PERMEN PU No.41/PRT/M/2007, areas that have rainfall levels with 
an intensity of 2,500-3000 are included in the high category with a weighting score of 40 , which is presented in Table 8. The same rainfall intensity, and the scoring results are presented in Table 9.

Table 8. The Scoring results for each class of rainfall

\begin{tabular}{cccc}
\hline $\begin{array}{c}\text { Rainfaal } \\
(\mathbf{m m} / \text { day })\end{array}$ & Class & Area (Ha) & Score \\
\hline $\mathbf{2 . 5 0 0 - 3 . 0 0 0}$ & High & 8849.957409 & 40 \\
\hline
\end{tabular}

Table 9. The scoring results for each class of rainfall at each resettlement location

\begin{tabular}{|c|c|c|}
\hline Resettlement Location & Class Of Rainfall & Score \\
\hline Kp Pasir Jegud/Tapos & High & 40 \\
\hline Kp. Cidongke & High & 40 \\
\hline Kp Munjul & High & 40 \\
\hline $\mathrm{Kp}$ Santik & High & 40 \\
\hline Kp Cihaneut & High & 40 \\
\hline Kp Cangkuang & High & 40 \\
\hline Kp Jolok & High & 40 \\
\hline Kp, Gunung Batu & High & 40 \\
\hline Kp Pasir Laja & High & 40 \\
\hline $\mathrm{Kp}$, Babakan Bandung & high & 40 \\
\hline
\end{tabular}

\subsection{Flood Risk}

The first disaster indicator discussed is flood risk, based on the results of the analysis on the flood risk map in the study area (Fig. 7), there are 2 classes of flood risk, namely Low Risk and Medium Risk.. The research area is dominated by a level of disaster with Moderate Risk of flooding with an area of $8,849,957409 \mathrm{Ha}$, while in an area that is quite risky it is $68,564477 \mathrm{Ha}$. The land suitability score for residential areas for flood risk indicators is shown in Table $\mathbf{1 0}$.

Tabel 10. The scoring result of flood risk.

\begin{tabular}{ccc}
\hline $\begin{array}{c}\text { Class Of Floding } \\
\text { Risk }\end{array}$ & Area (Ha) & Score \\
\hline Low Risk & $8.781,392932$ & 5 \\
\hline Moderate Risk & 68,564477 & 10 \\
\hline
\end{tabular}

As for the location of resettlement owned by residents, all locations or 10 locations are in an area with a Low Flood Risk class with the data presented in Table 11.

Tabel 11. The scoring results for each class of flood risk at each resettlement location.

\begin{tabular}{ccc}
\hline Resettlement Location & $\begin{array}{c}\text { Risk } \\
\text { Floding }\end{array}$ & Score \\
\hline Kp.Pasir Jegud/Tapos & Low Risk & 5 \\
\hline Kp. Cidongke & Low Risk & 5 \\
\hline Kp. Munjul & Low Risk & 5 \\
\hline Kp. Santik & Low Risk & 5 \\
\hline Kp. Cihaneut & Low Risk & 5 \\
\hline Kp. Cangkuang & Low Risk & 5 \\
\hline Kp. Jolok & Low Risk & 5 \\
\hline Kp. Gunung Batu & Low Risk & 5 \\
\hline Kp. Pasir Laja & Low Risk & 5 \\
\hline Kp. Babakan Bandung & Low Risk & 5 \\
\hline
\end{tabular}

\subsection{Landslide Risk}

For landslide risk based on landslide risk map analysis (Fig. 8), in the study area there are 3 classes of landslide risk, namely Low Risk with an area of $3,946,404492 \mathrm{Ha}$, Medium Risk with an area of $492,538149 \mathrm{Ha}$ and in the study area itself is dominated by the level of risk of disaster at risk. height with an area of 4,536.015929 Ha. Following are the results of the scoring carried out based on the value of landslide risk.

Tabel 12. The scoring result of landslide risk.

\begin{tabular}{ccc}
\hline Class Of Floding Risk & Area (Ha) & Score \\
\hline Low Risk & $3.946,404492$ & 5 \\
\hline Moderate Risk & 492,538149 & 10 \\
\hline High Risk & $4.536,015929$ & 15 \\
\hline
\end{tabular}

Meanwhile, for the resettlement locations of residents affected by the construction of the Cisokan Reservoir, of the 10 settlement locations, 5 are in lowrisk areas and 5 are in high-risk areas. For more details, the analysis results and landslide risk scoring are presented in Table 13.

Tabel 13. The scoring results for each class of flood risk at each resettlement location.

\begin{tabular}{ccc}
\hline Resettlement Location & Risk Floding & Score \\
\hline Kp.Pasir Jegud/Tapos & Low Risk & 5 \\
\hline Kp. Cidongke & Low Risk & 5 \\
\hline Kp. Munjul & Low Risk & 5 \\
\hline Kp. Santik & Low Risk & 5 \\
\hline Kp. Cihaneut & High Risk & 15 \\
\hline Kp. Cangkuang & High Risk & 15 \\
\hline Kp. Jolok & High Risk & 15 \\
\hline Kp. Gunung Batu & High Risk & 15 \\
\hline Kp. Pasir Laja & High Risk & 15 \\
\hline Kp. Babakan Bandung & Low Risk & 5 \\
\hline
\end{tabular}

\subsection{Earthquake Vulnerability}

Based on the results of earthquake hazard map analysis, the research location is dominated by the Low Vulnerability class with an area of 3,804,63516 Ha, followed by the High Vulnerability class with an area of $3,758,198724 \mathrm{Ha}$ while for areas that have an earthquake risk class the Medium Vulnerability class is $1231,16744 \mathrm{Ha}$. Based on the class obtained, the following scoring results are presented in the Table 14.

Table 14. The scoring result of earthquake vulnerability

\begin{tabular}{ccc}
\hline $\begin{array}{c}\text { Class Of Floding } \\
\text { Vulnerability }\end{array}$ & Area (Ha) & Score \\
\hline Low & $3.804,63516$ & 5 \\
\hline Moderate & $1.231,16744$ & 10 \\
\hline High & $3.758,198724$ & 15 \\
\hline
\end{tabular}

Meanwhile, based on the earthquake disaster map at the research location, for the resettlement area of residents from 10 locations 6 locations are in the High earthquake disaster class, while 2 locations are in the Moderate class areas, and 2 locations are in areas with Low earthquake Vulnerability class. The scoring results for each resettlement location are presented in the Table 15. 
Tabel 15. The scoring results for each class of earthquake vulnerability.

\begin{tabular}{ccc}
\hline Resettlement Location & $\begin{array}{c}\text { Earthquake } \\
\text { Vulnerability }\end{array}$ & Score \\
\hline Kp.Pasir Jegud/Tapos & High & 15 \\
\hline Kp. Cidongke & High & 15 \\
\hline Kp. Munjul & Moderate & 10 \\
\hline Kp. Santik & High & 15 \\
\hline Kp. Cihaneut & High & 15 \\
\hline Kp. Cangkuang & Low & 5 \\
\hline Kp. Jolok & High & 15 \\
\hline Kp. Gunung Batu & High & 15 \\
\hline Kp. Pasir Laja & Low & 5 \\
\hline Kp. Babakan Bandung & Moderate & 10 \\
\hline
\end{tabular}

\subsection{Land Suitability Evaluation}

Evaluation of land suitability in the resettlement location of residents affected by the construction of the Cisokan reservoir is carried out as an effort to assess and determine the extent of the relationship between spatial planning and planning and land suitability. So that people get a large ratio of benefits from the existence of a development, especially the surrounding communities and communities that are directly affected by the development. In this case, people who have to move to another place get a decent, safe and orderly place to live in a physical environment so as to guarantee and ensure the sustainability of community life.

With the scoring method and map overlay on all physical indicators in this study, it is known through the land suitability map for the resettlement area of residents affected by the construction of the Cisokan Reservoir, which is shown in Figure. From the results of map analysis at the research location, it was obtained 3 classes of land suitability for residential areas, namely S1, S2, and S3. Meanwhile, the suitability class N was not found at the research location based on the scoring results obtained.

The study area is dominated by land suitability class S2 (Moderate Match) with an area of 4008.537697 $\mathrm{Ha}$ or $45.30 \%$ and is followed by S3 (Marginally Suitable) land suitability class with a total area of $3966.448866 \mathrm{Ha}$ or $44.82 \%$ of the total area, and the last is the suitability class. S1 (Highly Suitable) land with an area of 874.97 hectares or $9.88 \%$ of the total area. Meanwhile, based on the results of the scoring in the study area, there was no land suitability class $\mathrm{N}$ (Currently Not Suitable). To make it easier to understand the scoring results are shown in the Table 16.

Table 16. The scoring result for land suitability evaluation.

\begin{tabular}{ccc}
\hline $\begin{array}{c}\text { Land Suitability } \\
\text { Class }\end{array}$ & Area (Ha) & Percentage \\
\hline S1 & 874,97 & $9,88 \%$ \\
\hline S2 & 4008,537697 & $45,30 \%$ \\
\hline S3 & 3966,448866 & $44,82 \%$ \\
\hline N & 0 & $0 \%$ \\
\hline Total & 8849,957409 & $100 \%$ \\
\hline
\end{tabular}

Meanwhile, in the resettlement location of residents affected by the construction of the Cisokan Reservoir. Based on the total calculation of the scoring results for each specific indicator at 10 resettlement locations, all locations or 10 resettlement locations for residents are included in areas with land suitability class S2. For more details on land suitability classes at each resettlement location, it is presented in Table 17.

Table 17. The results of scoring and weighting of land suitability classes at the resettlement location.

\begin{tabular}{ccc}
\hline Resettlement Location & Total score & $\begin{array}{c}\text { Land Suitability } \\
\text { Class }\end{array}$ \\
\hline Kp.Pasir Jegud/Tapos & 165 & S2 \\
\hline Kp. Cidongke & 195 & S2 \\
\hline Kp. Munjul & 170 & S2 \\
\hline Kp. Santik & 195 & S2 \\
\hline Kp. Cihaneut & 205 & S2 \\
\hline Kp. Cangkuang & 165 & S2 \\
\hline Kp. Jolok & 175 & S2 \\
\hline Kp. Gunung Batu & 175 & S2 \\
\hline Kp. Pasir Laja & 195 & S2 \\
\hline Kp. Babakan Bandung & 190 & S2
\end{tabular}

From the results of this study, it is known that the study area is dominated by land suitability class S2 (Moderate Match) which states that the land has boundaries for sustainable application (Table 1). Likewise in the spatial planning and resettlement areas of residents affected by the construction of the Cisokan reservoir, all locations are in areas with a S2 suitability class even though the relocation process is carried out independently by residents, with the majority of residents arguing that the resettlement location of residents is very supportive of them gaining accessibility to resources. land power is due to the fact that most of the residents have a daily habit of being farmers, who always make use of natural resources in their lives.

However, in this case, although the majority of residents do not have or get sufficient information about the suitability of land that is suitable for their residential areas, in several cases it is found that agrarian communities have a tendency to be spatial and structured, one of which is in the selection of settlement locations. Where this is the result of experience and a long learning process, and produces natural instincts in building housing, rice fields, cultural places, places of worship, and places of gathering. In this process, it produces a spatial process in life that is used by residents as an effort to maintain life and adapt to physical environmental conditions, social environmental conditions, including culture.

\section{Conclusion}

In conclusion, the research area based on 5 village boundaries, namely the area of Sukaresmi Village, Cicadas Village, Bojong Salam Village, Bojong Village, and Cinengah Village, there are 3 land suitability classes for settlement, namely S1, S2 and S3. Meanwhile, the suitability class $\mathrm{N}$ was not found in the study area. The research area itself is dominated by $\mathrm{S} 2$ suitability class.Meanwhile, for the resettlement locations of residents affected by the construction of the Cisokan reservoir, all locations are in the S2 land suitability class with an area of $4008.537697 \mathrm{Ha}$ or $45.30 \%$ and followed by S3 land suitability class with a total area of 3966, 
$448866 \mathrm{Ha}$ or $44.82 \%$ of the total area, and the last one is land suitability S1 with an area of 874.97 hectares or $9.88 \%$ of the total area.

\section{Acknowledgements}

This study is supported by the Department of Master of Environmental Sciences, Faculty of Postgraduate School, Padjadjaran University. The author would like to thank the entire monitoring team for the 2020 LARAP report preparation, so that this research can be carried out.

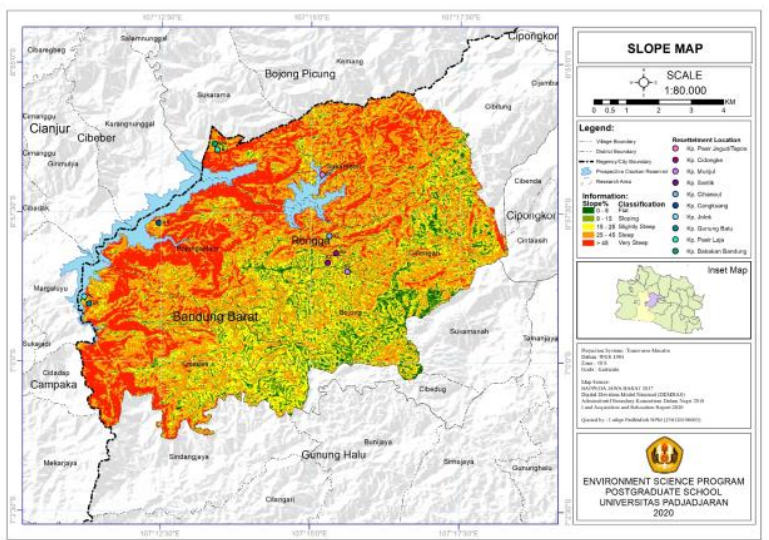

Fig. 3. Slope Map In The Research Area

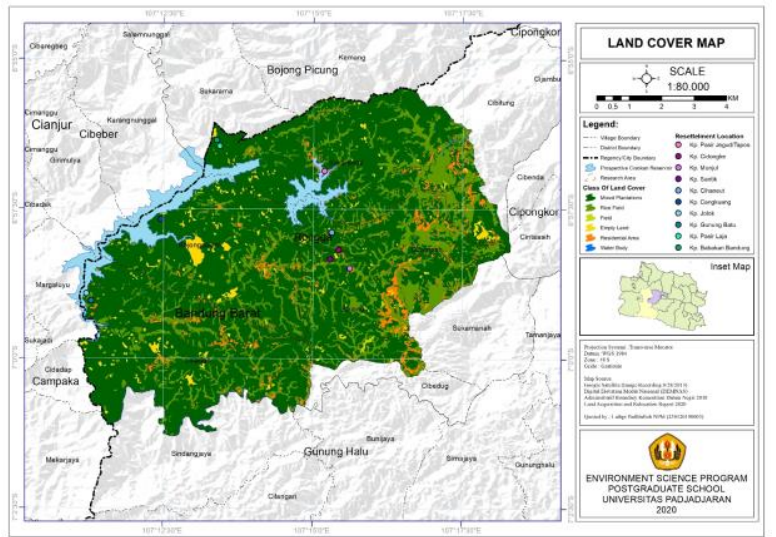

Fig. 4. Land Cover Map In The Research Area

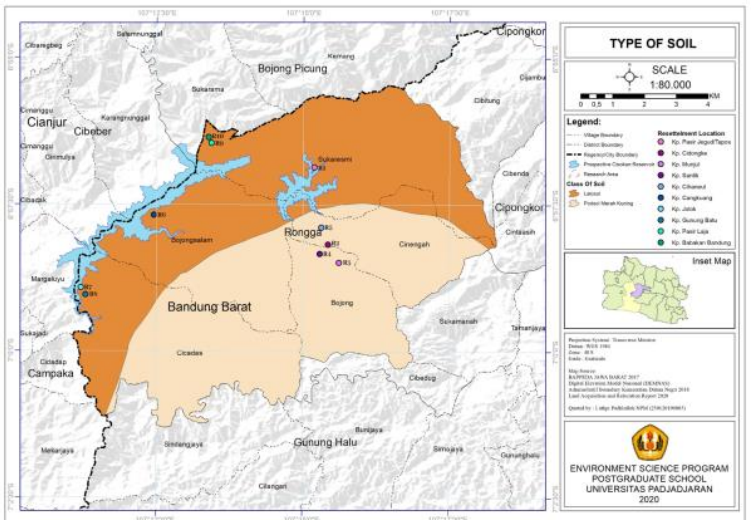

Fig. 5. Type Of Soil Map In The Research Area

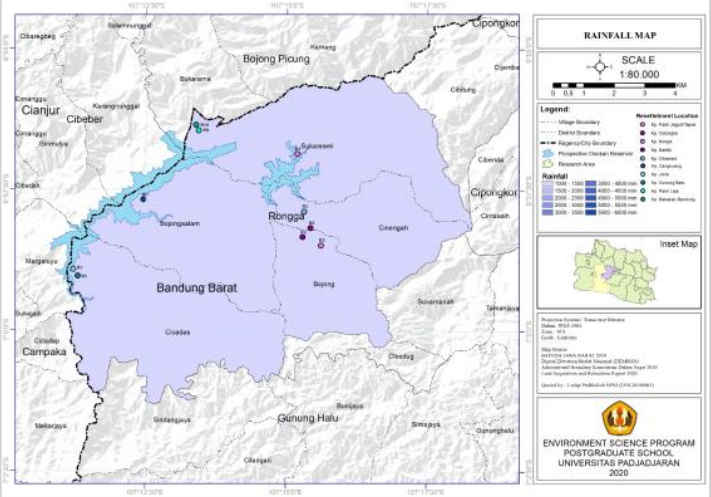

Fig. 6. Rainfall Map In The Research Area

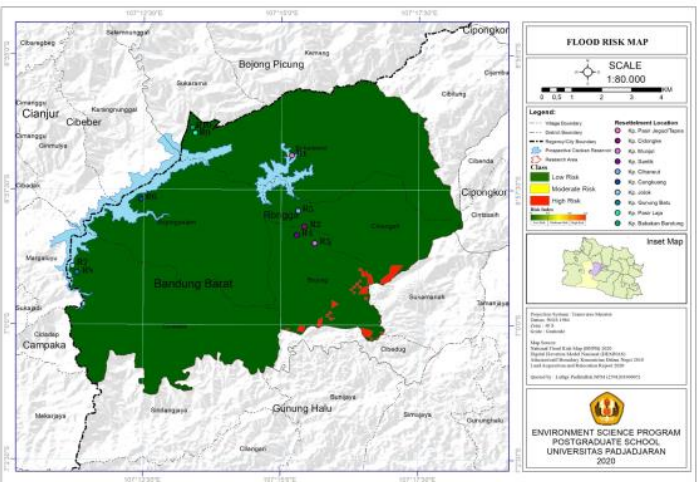

Fig. 7. Flood Risk Map In The Research Area

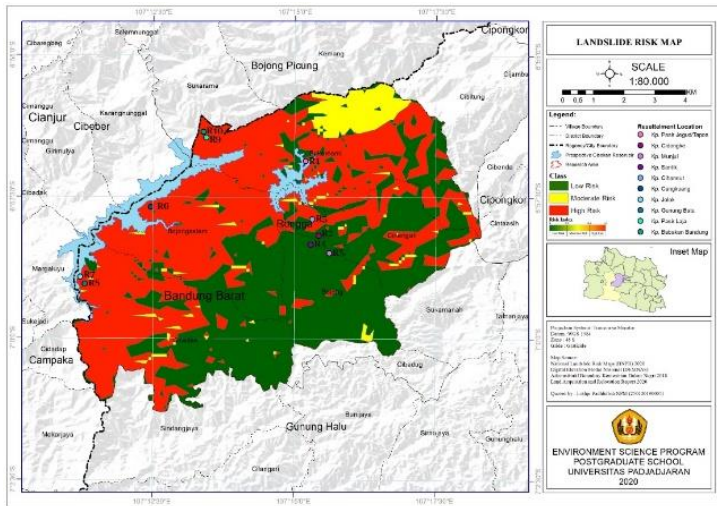

Fig. 8. Landslide Risk Map In The Research Area

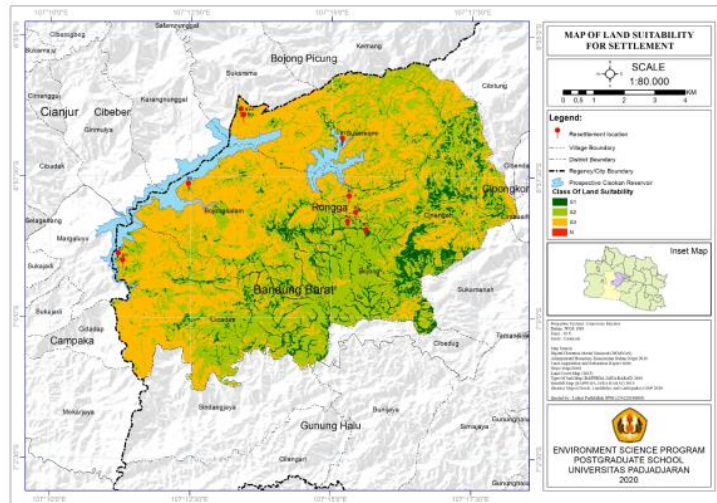

Fig. 9. Map Of Land Suitability For Settlement In The Research Area 


\section{References}

1. Abdullah, S, Oekan, Ekologi Manusia dan Pembangunan Berkelanjutan. Gramedia Pustaka Utama. Jakarta. [Indonesia] (2017)

2. Fearnside, P. M,. Impacts of Brazil's Madeira River dams: Unlearned lessons for hydroelectric development inAmazonia.Environmental Science\&Policy. [Brazil] (2014)

3. Fearnside, P. M., Hidrelétricas na Amazônia: Impactos ambientais e sociais na tomada de decisões sobre grandes obras. Manaus: Editora do INPA. [Brazil] (2015)

4. Hermawati, R., Suwartpradja S Opan \& Wijayanto V., Perubahan Mata penceharian dan proses adaptasi warga terkena dampak pembangunan waduk jatigede. Journal Of Anthropology. Universitas Padjadjaran. Sumedang. [Indonesia] (2017)

5. Johan, Iskandar, Ekologi Manusia dan Pembangunan Berkelanjutan. Magister Imu Lingkungan Universitas Padjadjaran. Bandung. [Indonesia] (2017)

6. Moretto, E. M., Gomes, C. S., Roquetti, D. R., \& Jordão, C. de O., Histórico, tendências e perspectivas no planejamento espacial de usinas hidrelétricas brasileiras: A antiga e atual fronteira Amazônica. Ambiente \& Sociedade, 15(3), 141164. [Brazil] (2012)

7. PLN Inc., Land Acquisition And Resettlement Action Plan (LARAP) Upper Cisokan Pumped Storage (UCPS) (2020)

8. PLN, (2020). Statistik PLN (2019)

9. Soemarwoto, Otto., Ekologi, Lingkungan Hidup dan Pembangunan. Djambatan. Jakarta. [Indonesia] (2004)

10. Soemarwoto Otto, Analisis Mengenai Dampak Lingkungan. Gadjah Mada University Press. Yogyakarta. [Indonesia] (2009)

11. Yasin,Tian., Xuesong, Kong., Yaolin, Liu. Combining weight daily life circle and land suitability for rural settlement reconstruction. School of Resourse and Environmental Science., Key laboratory of Geographic Information System, Ministry of Education, Wuhan University.[China] (2018) 